\title{
FRUIT ORIENTATION ALTERS THE QUALITY OF LITCHI (LITCHI CHINENSIS SONN.) UNDER THE AGRO-CLIMATIC CONDITIONS OF EASTERN INDIA
}

\author{
NARAYAN LAL ${ }^{1 *}$, VISHAL NATH ${ }^{2}$ \\ ${ }^{1}$ ICAR-Indian Institute of Soil Science, Bhopal, Madhya Pradesh, India. ${ }^{2}$ ICAR-National Research Centre on Litchi, Muzaffarpur, Bihar. \\ Email: narayanlal.lal7@gmail.com
}

Received: 05 January 2021, Revised and Accepted: 26 March 2021

\section{ABSTRACT}

Objective: The experiment was conducted on ten litchi cultivars, namely; Purbi, Bedana, Lal Bombay, Mandaraji, Calcuttia, Late Bedana, Trikolia, Dehradoon, Dehrarose, and Seedless No. 2 to assess the physical and chemical composition of fruit as affected by fruit orientation on the tree.

Methods: Fruits were picked both from the lower and upper half portion of the tree at fully ripened stage and physio-chemical attributes were analyzed.

Results: The result indicated that fruits at lower half portion were not only heavy in weight but also had more percentage of total acidity. However, stone weight, ascorbic acid content, and total sugars were found to be more in fruits collected from the upper half portion of the tree.

Conclusion: It can be suggested that picking should be started from those fruits which are positioned at the lower half portion of the tree to collect fruits of superior quality.

Keywords: Cultivars, Physical, Chemical, Orientation, Lower, Upper

(C) 2021 The Authors. Published by Innovare Academic Sciences Pvt Ltd. This is an open access article under the CC BY license (http://creativecommons. org/licenses/by/4.0/] DOI: http://dx.doi.org/10.22159/ijags.2021v9i3.40709. Journal homepage: https://innovareacademics.in/journals/index.php/ijags

\section{INTRODUCTION}

Litchi (Litchi chinensis Sonn.) is an evergreen subtropical fruit tree and important member of family Sapindaceae having more than 400 species [1] which has strong mycorrhizal association [2]. It is known as Chinese Cherry, Leechee, Lichee, Litchi, Mountain Litchi and Water Litchi [3]. The litchi is one of the most environmentally sensitive fruit tree [4] restricted to few a countries in the world and in few states in India. Recently, it has been reported that litchi is performing well in Southern parts of India [5]. Litchi commenced flowering during February-March in Bihar condition and intensity of flowering depends on the previous year's fruiting, temperature during floral bud differentiation, phenol content [6] and age of plants [7,8]. A single panicle produced hundreds to thousands of flowers and success of fruit set depends on the pollen grain received from male parents $[9,10]$. The litchi fruit ripens during summer when the atmospheric temperature is high. Nowadays, quality is very important than quantity to attract the consumer. The position of fruit on tree has influence on the quantity and quality of fruit. A wide variation in litchi fruit quality parameters, that is, TSS (17.04-19.98 Brix), ascorbic acid (14.62-47.50 mg 100/g), acidity (0.23-0.55\%), total sugar (10.05$13.54 \%)$, reducing sugar (7.69-10.78\%), and TSS/acidity ratio (33.98$84.19)$ and phenolics and flavonoids have been reported [11,12]

Seasonal variations in temperature are very important for proper fruiting. The temperature should not go beyond $40-45^{\circ} \mathrm{C}$ in summer and below the freezing point in winter. The fluctuation in temperature during development of fruit affect fruit drop [13]. Pericarp browning is severe post-harvest problem [14] and high temperature causes fruit cracking and sun burn in the field [15]. Nutrients and plant growth regulators also affected fruit set, yield, and quality of fruits [16-18]. The yield and quality of fruits are affected by number of factors including aberrant weather. Among this orientation of the fruit on the tree play a marvelous role in influencing the quality of the fruit [19]. This paper describes the effect of fruit orientation of litchi on its quality in agroclimatic conditions of Eastern India.

\section{METHODS}

An experiment was conducted in 2017-2018 at National Active Germplasm Site, ICAR-National Research Centre on Litchi, Muzaffarpur (Bihar) located at $26^{\circ} 5^{\prime} 87^{\prime \prime} \mathrm{N}$ latitude, $85^{\circ} 26^{\prime} 64^{\prime \prime} \mathrm{E}$ longitude at an elevation of $210 \mathrm{~m}$ above msl to assess the effect of fruit orientation on quality. The soil type of the site was alluvial with sandy loam texture having calcareous in nature with $\mathrm{pH}$ ranging from 7.5 to 8.0. The temperature varied from $30^{\circ} \mathrm{C}$ to $43^{\circ} \mathrm{C}$ in summer and $5^{\circ} \mathrm{C}$ to $10^{\circ} \mathrm{C}$ in winter. The region was characterized by dry and hot summer and cold winter with heavy rainfall during rainy season. The onset of monsoon usually occurs in the $2^{\text {nd }}$ or $3^{\text {rd }}$ week of June and continues in appreciable amount up to mid of September. Trees of the same size and age (about 10 years old) were selected for the study. The Fruits of each cultivar were picked from the upper half and lower half positions of the same tree. The experiment was replicated thrice using two factors in RCBD with varieties and exposure. Fruit weight (g), pulp or edible portion (g), and seed weight (g) were determined. Titratable acidity (\%), total sugar (\%), ascorbic acid (mg/100 g), and TSS (Brix) were determined from extracted juice. The data were subjected to analysis of variance [20]. The level of probability was tested at $5 \%$ level of significance. Critical difference (CD) values were calculated wherever the $\mathrm{F}$ test was found to be significant.

\section{RESULTS AND DISCUSSION}

All the means of the various parameters showed significant differences $(\mathrm{p}<0.005)$. The maximum fruit weight was recorded in Calcuttia (23.03 g), followed by Mandaraji (22.45 g). Fruit positioned at the lower half had greater fruit weight (23.24 g) than the upper half of the tree (Table 1). Similar results have been reported in litchi $[21,22]$ and other fruit crops like citrus [23] who reported higher fruit weight in citrus fruits located at lower half portion. However, fruit weight is also affected by fruit load [24]. Maximum pulp weight was found in Late Bedana (14.27 g), followed by Dehradoon (14.22 g), while the 
Table 1: Fruit and pulp weight of litchi as influenced by fruit orientation on the tree

\begin{tabular}{|c|c|c|c|c|c|c|}
\hline \multirow[t]{2}{*}{ Cultivars } & \multicolumn{3}{|c|}{ Fruit weight (g) } & \multicolumn{3}{|c|}{ Pulp weight (g) } \\
\hline & $\begin{array}{l}\text { Lower- } \\
\text { half }\end{array}$ & $\begin{array}{l}\text { Upper- } \\
\text { half }\end{array}$ & Mean & $\begin{array}{l}\text { Lower- } \\
\text { half }\end{array}$ & $\begin{array}{l}\text { Upper- } \\
\text { half }\end{array}$ & Mean \\
\hline Bedana & $16.22^{\mathrm{e}}$ & $16.16^{\mathrm{d}}$ & $16.19^{\mathrm{e}}$ & $12.37^{c}$ & $12.31^{\mathrm{d}}$ & $12.34^{\mathrm{c}}$ \\
\hline Lal Bombay & $18.88^{d}$ & $18.92^{c}$ & $18.90^{\mathrm{d}}$ & $9.95^{\mathrm{d}}$ & $9.91^{\mathrm{e}}$ & $9.93^{d}$ \\
\hline Mandaraji & $22.48^{\mathrm{a}}$ & $22.42^{\mathrm{a}}$ & $22.45^{\mathrm{ab}}$ & $12.54^{c}$ & $12.48^{\mathrm{bcd}}$ & $12.51^{\mathrm{bc}}$ \\
\hline Purbi & $22.30^{\mathrm{a}}$ & $22.18^{\mathrm{a}}$ & $22.24^{\mathrm{ab}}$ & $12.8^{\mathrm{bc}}$ & $12.84^{\mathrm{bc}}$ & $12.82^{\mathrm{abc}}$ \\
\hline Calcuttia & $23.24^{\mathrm{a}}$ & $22.82^{\mathrm{a}}$ & $23.03^{\mathrm{a}}$ & $13.20^{\mathrm{b}}$ & $12.90^{\mathrm{b}}$ & $13.05^{\mathrm{abc}}$ \\
\hline Late Bedana & $19.86^{\mathrm{cd}}$ & $20.08^{b}$ & $19.97^{\mathrm{cd}}$ & $14.28^{\mathrm{a}}$ & $14.26^{\mathrm{a}}$ & $14.27^{\mathrm{a}}$ \\
\hline Trikolia & $20.95^{\mathrm{bc}}$ & $20.87^{\mathrm{b}}$ & $20.91^{b c}$ & $12.30^{c}$ & $12.32^{\mathrm{d}}$ & $12.35^{c}$ \\
\hline Dehrarose & $22.42^{\mathrm{a}}$ & $22.36^{\mathrm{a}}$ & $22.39^{\mathrm{ab}}$ & $12.47^{c}$ & $12.39^{\mathrm{cd}}$ & $12.43^{c}$ \\
\hline Seedless No 2 & $18.95^{\mathrm{d}}$ & $18.85^{c}$ & $18.90^{\mathrm{d}}$ & $9.92^{\mathrm{d}}$ & $9.84^{\mathrm{e}}$ & $9.88^{d}$ \\
\hline Dehradoon & $22.00^{\mathrm{ab}}$ & $20.06^{\mathrm{b}}$ & $21.03^{b c}$ & $14.24^{\mathrm{a}}$ & $14.20^{\mathrm{a}}$ & $14.22^{\mathrm{ab}}$ \\
\hline Mean & 20.73 & 20.47 & & 12.42 & 12.35 & \\
\hline
\end{tabular}

lowest pulp weight was observed in Seedless No. 2 (9.88 g). Significant $(\mathrm{p}<0.005)$ effect of fruit orientation was observed at the lower half. It had more pulp weight than the fruit collected from the upper half of the tree (Table 1).

Calcuttia showed significantly high seed weight (3.96 g) which was at par Dehardoon (3.91 g), while Bedana showed minimum seed weight $(1.70 \mathrm{~g})$. Seed weight of fruit positioned at the upper half of the tree was greater than the lower half (Table 2). Thus, lower half portion of tree produced good quality of fruits. These results are agreement with earlier workers $[21,25]$.

Mean differences for acidity (\%) are presented in Table 3 which is highly significant at $5 \%$ level of probability. The highest total acidity was recorded in Seedless No. 2 and Purbi variety (0.51\%). The interaction shows that Seedless No. 2 had maximum total acidity $(0.55 \%)$ when its fruits were positioned at lower half part of the tree. Results depicted that the fruit oriented at lower half had more percentage of acidity. Earlier worker [25] also find same trends of result but these do not coincide with the findings of other [26] who reported non-significant results for the trait under consideration for orientation factor. The variation in findings might be due to fluctuated environmental components as well fruit production inputs. The mean differences of ascorbic acid among varieties were significant while interaction was non-significant (Table 3). Late Bedana with ascorbic acid content $(40.50 \mathrm{mg} / 100 \mathrm{gm})$ was at the top amongst others. The lowest ascorbic acid content was noted in Trikolia $(16.78 \mathrm{mg} / 100 \mathrm{~g})$. Non-significant effect of orientation was observed for ascorbic acid. The fruits positioned at lower half in Late Bedana had the maximum ascorbic acid contents $(42.68 \mathrm{mg} / 100 \mathrm{~g})$. Ascorbic acid content in litchi fruit was observed higher in the fruits located at the lower half portion of the tree. The similar results also advocated by others $[25,27]$.

Total sugar percentage was the highest (14.75\%) in fruits of Trikolia. The least percentage of total sugars was recorded in Seedless No. 2 cv. $(8.67 \%)$. Results obtained for total sugars percentage revealed that orientation factor had no effect on fruit quality as also reported by other [21]. It is evident from Table 4 that means of varieties as well as their interaction for total soluble solids differ significantly. However, the mean differences for orientation were non-significant. Late Bedana variety had the maximum total soluble solids. The minimum value of TSS was recorded in Lal Bombay cultivar. However, variety Dehradoon was the closest to Late Bedana with regard to total soluble solids. The interaction between variety and orientation was noted significant for total soluble solids. Maximum soluble solids were recorded in Late Bedana cultivar where fruits were positioned at lower half of the tree. No significant effect of the orientation relating total soluble solids in litchi fruit had been observed by earlier workers $[25,26]$ who found fewer amounts of soluble solids in fruits for the orientation factor. The difference in results might be due to varietal differences, changed environment as well as difference in the type of fruit.
Table 2: Seed weight of litchi as influenced by fruit orientation on the tree

\begin{tabular}{llll}
\hline Cultivars & Lower-half & Upper-half & Mean \\
\hline Bedana & $1.75^{\mathrm{f}}$ & $1.77^{\mathrm{f}}$ & $1.76^{\mathrm{f}}$ \\
Lal Bombay & $3.05^{\mathrm{d}}$ & $3.07^{\mathrm{e}}$ & $3.06^{\mathrm{e}}$ \\
Mandaraji & $3.38^{\mathrm{c}}$ & $3.42^{\mathrm{d}}$ & $3.40^{\mathrm{cd}}$ \\
Purbi & $3.33^{\mathrm{c}}$ & $3.87^{\mathrm{abc}}$ & $3.60^{\mathrm{bc}}$ \\
Calcuttia & $3.92^{\mathrm{a}}$ & $4^{\mathrm{a}}$ & $3.96^{\mathrm{a}}$ \\
Late Bedana & $1.9^{\mathrm{e}}$ & $1.88^{\mathrm{f}}$ & $1.89^{\mathrm{f}}$ \\
Trikolia & $3.8^{\mathrm{ab}}$ & $3.82^{\mathrm{bc}}$ & $3.81^{\mathrm{ab}}$ \\
Dehrarose & $3.72^{\mathrm{b}}$ & $3.76^{\mathrm{c}}$ & $3.74^{\mathrm{ab}}$ \\
Seedless No 2 & $3.25^{\mathrm{c}}$ & $3.29^{\mathrm{d}}$ & $3.27^{\mathrm{de}}$ \\
Dehradoon & $3.9^{\mathrm{a}}$ & $3.92^{\mathrm{ab}}$ & $3.91^{\mathrm{a}}$ \\
Mean & 3.2 & 3.28 & \\
\hline
\end{tabular}

Table 3: Total acidity as influenced by fruit orientation on tree

\begin{tabular}{|c|c|c|c|c|c|c|}
\hline \multirow[t]{2}{*}{ Cultivars } & \multicolumn{3}{|c|}{ Total acidity (\%) } & \multicolumn{3}{|c|}{ Ascorbic acid (mg/100g) } \\
\hline & $\begin{array}{l}\text { Lower- } \\
\text { half }\end{array}$ & $\begin{array}{l}\text { Upper- } \\
\text { half }\end{array}$ & Mean & $\begin{array}{l}\text { Lower- } \\
\text { half }\end{array}$ & $\begin{array}{l}\text { Upper- } \\
\text { half }\end{array}$ & Mean \\
\hline Bedana & $0.42^{\mathrm{d}}$ & $0.32^{\mathrm{e}}$ & $0.37^{c}$ & $28.68^{c}$ & $31.78^{b}$ & $30.23^{b}$ \\
\hline Lal Bombay & $0.3^{8 f}$ & $0.28^{\mathrm{f}}$ & $0.33^{\mathrm{d}}$ & $25.68^{d}$ & $23.48^{\mathrm{d}}$ & $24.58^{\text {cd }}$ \\
\hline Mandaraji & $0.4^{\mathrm{e}}$ & $0.36^{\mathrm{d}}$ & $0.38^{c}$ & $18.67^{g}$ & $15.97^{\mathrm{f}}$ & $17.32^{\mathrm{e}}$ \\
\hline Purbi & $0.48^{\mathrm{b}}$ & $0.54^{\mathrm{a}}$ & $0.51^{\mathrm{a}}$ & $20.48^{\mathrm{f}}$ & $24.08^{\mathrm{d}}$ & $22.28^{\mathrm{d}}$ \\
\hline Calcuttia & $0.45^{c}$ & $0.39^{c}$ & $0.42^{\mathrm{b}}$ & $21.68^{\mathrm{e}}$ & $27.66^{c}$ & $24.67^{\mathrm{cd}}$ \\
\hline Late Bedana & $0.48^{\mathrm{b}}$ & $0.38^{\mathrm{cd}}$ & $0.43^{\mathrm{b}}$ & $42.68^{\mathrm{a}}$ & $38.32^{\mathrm{a}}$ & $40.50^{\mathrm{a}}$ \\
\hline Trikolia & $0.27^{\mathrm{h}}$ & $0.21^{\mathrm{h}}$ & $0.24^{\mathrm{e}}$ & $14.68^{\mathrm{h}}$ & $18.88^{e}$ & $16.78^{\mathrm{e}}$ \\
\hline Dehrarose & $0.29^{\mathrm{g}}$ & $0.21^{\mathrm{h}}$ & $0.25^{\mathrm{e}}$ & $21.58^{\mathrm{e}}$ & $27.66^{c}$ & $24.62^{\text {cd }}$ \\
\hline Seedless No 2 & $0.55^{\mathrm{a}}$ & $0.47^{\mathrm{b}}$ & $0.51^{\mathrm{a}}$ & $28.67^{c}$ & $23.63^{d}$ & $26.15^{c}$ \\
\hline Dehradoon & $0.28^{\mathrm{gh}}$ & $0.24^{g}$ & $0.26^{\mathrm{e}}$ & $30.75^{b}$ & $32.07^{b}$ & $31.41^{\mathrm{b}}$ \\
\hline Mean & $0.40^{\mathrm{a}}$ & $0.34^{\mathrm{b}}$ & & 25.36 & 26.35 & \\
\hline
\end{tabular}

Mean followed by similar letter do not differ significantly at $\mathrm{p}=0.05$

Table 4: Total sugar (\%) of litchi as affected by fruit orientation on the tree

\begin{tabular}{|c|c|c|c|c|c|c|}
\hline \multirow[t]{2}{*}{ Cultivars } & \multicolumn{3}{|c|}{ Total sugar (\%) } & \multicolumn{3}{|c|}{ TSS (Brix) } \\
\hline & $\begin{array}{l}\text { Lower- } \\
\text { half }\end{array}$ & $\begin{array}{l}\text { Upper- } \\
\text { half }\end{array}$ & Mean & $\begin{array}{l}\text { Lower- } \\
\text { half }\end{array}$ & $\begin{array}{l}\text { Upper- } \\
\text { half }\end{array}$ & Mean \\
\hline Bedana & $12.45^{\mathrm{b}}$ & $7.79^{g}$ & $10.12^{\mathrm{e}}$ & $16.57^{\mathrm{e}}$ & $18.47^{\mathrm{c}}$ & $17.52^{\mathrm{bcd}}$ \\
\hline Lal Bombay & $12.68^{\mathrm{b}}$ & $7.58^{\mathrm{g}}$ & $10.13^{\mathrm{e}}$ & $19.48^{\mathrm{ab}}$ & $14.6^{\mathrm{f}}$ & $17.04^{\mathrm{d}}$ \\
\hline Mandaraji & $9.75^{\mathrm{e}}$ & $12.41^{\mathrm{d}}$ & $11.08^{\text {abcde }}$ & $16.75^{\mathrm{e}}$ & $19.05^{\mathrm{bc}}$ & $17.90^{\mathrm{bcd}}$ \\
\hline Purbi & $9.37^{\mathrm{e}}$ & $12.73^{\mathrm{cd}}$ & $11.05^{\text {bcde }}$ & $18.00^{\mathrm{cd}}$ & $19^{\mathrm{bc}}$ & $18.50^{\mathrm{bc}}$ \\
\hline Calcuttia & $10.48^{\mathrm{d}}$ & $14.68^{\mathrm{a}}$ & $12.58^{\mathrm{a}}$ & $19.37^{\mathrm{b}}$ & $16.79^{\mathrm{d}}$ & $18.08^{\mathrm{bcd}}$ \\
\hline Late Bedana & $12.68^{\mathrm{b}}$ & $8.24^{\mathrm{f}}$ & $10.46^{\text {de }}$ & $20.12^{\mathrm{a}}$ & $19.76^{\mathrm{ab}}$ & $19.94^{\mathrm{a}}$ \\
\hline Trikolia & $14.75^{\mathrm{a}}$ & $10.13^{\mathrm{e}}$ & $12.44^{\mathrm{ab}}$ & $17.85^{\mathrm{cd}}$ & $18.65^{c}$ & $18.25^{\mathrm{bcd}}$ \\
\hline Dehrarose & $10.28^{d}$ & $13.78^{b}$ & $12.03^{\mathrm{abc}}$ & $17.28^{\mathrm{de}}$ & $18.80^{c}$ & $18.04^{\mathrm{bcd}}$ \\
\hline Seedless No 2 & $8.67^{\mathrm{f}}$ & $13.03^{c}$ & $10.85^{\text {cde }}$ & $18.56^{c}$ & $15.82^{\mathrm{e}}$ & $17.19^{\mathrm{cd}}$ \\
\hline Dehradoon & $11.24^{\mathrm{c}}$ & $12.42^{\mathrm{d}}$ & $11.83^{\mathrm{abcd}}$ & $17.12^{\mathrm{e}}$ & $20.24^{\mathrm{a}}$ & $18.68^{\mathrm{ab}}$ \\
\hline Mean & 11.24 & 11.28 & & 18.11 & 18.12 & \\
\hline
\end{tabular}

\section{CONCLUSION}

Fruit orientation and picking system have a great impact on yield and quality of fruits. Results revealed that the lower half should need to pick first because litchi of this portion carry more pulp in comparison to the upper half. In addition, litchi of this region contains blond amount of nutrition and small stone. Hence, regarding agro-economic point, the farmers of this region should imply the above mentioned fruit orientation and harvesting methods.

\section{REFERENCES}

1. Lal N, Gupta AK, Kushwah NS, Nath V. Sapindaceous fruits: In: Peter $\mathrm{KV}$, editor. Horticultural Crops of High Nutritive Values. New Delhi: Brillion Publishing; 2017.

2. Lal N, Nath V. Effect of plant age and stress on flowering in litchi 
(Litchi chinensis). Curr Hortic 2020;8:24-7.

3. Marboh ES, Gupta AK, Singh M, Lal N, NathV. In: Peter KV, editor Litchi in Origin and Biological Diversity of Horticultural Crops. New Delhi: Brillion Publishing; 2019.

4. Lal N. Genetic Studies of Litchi Germ Plasm. Jabalpur, MP: Thesis, Submitted to JNKVV; 2018.

5. Nath V, Kumar AA, Pandey SD, Tripathi PC. Litchi in winter seasonaway forward. Indian Hortic 2015;59:26-7.

6. Lal N, Marboh ES, Gupta AK, Kumar A, Anal AK, Nath V. Variation in leaf phenol content during flowering in litchi (Litchi chinensis Sonn). J Exp Biol Agric Sci 2019; 7:569-73.

7. Lal N, Gupta AK, Kumar A, Nath V. Effect of age and strain of plants in litchi on flowering. Litchima 2018;4:46-8.

8. Lal N, Singh A, Gupta AK, Marboh ES, Kumar A, Nath N. Precocious flowering and dwarf NRCL-29-a new genetic stock of litchi (Litchi chinensis Sonn). Chem Sci Rev Lett 2019;8:206-10.

9. Lal N, Gupta AK, Marboh ES, Kumar A, Nath N. Effect of pollen grain sources on success of hybrids in "Bedana" litchi. Int J Bio Resour Stress Manag 2019;10:241-45.

10. Lal N, Gupta AK, Marboh ES, Kumar A, Nath V. Effect of pollen grain sources on fruit set and retention in "Shahi" litchi. Multilogic Sci 2019;9:152-6.

11. Lal N, Pandey SK, Nath V, Gontia AS, Sharma HL. Evaluation of litch (Litchi chinenesis Sonn) genotypes for fruit quality attributes. Int J Chem Stud 2018;6:2556-60.

12. Lal N, Pandey SK, Nath V, Agrawal V, Gontia AS, Sharma HL. Total phenol and flavonoids in by-product of Indian litchi: Difference among genotypes. J Pharmacogn Phytochem 2018;7:2891-4.

13. Lal N, Gupta AK, Nath V. Fruit retention in different litchi germ plasm influenced by temperature. Int J Curr Microbiol Appl Sci 2017;6:1189-94.

14. Purbey SK, Pongener A, Marboh ES, Lal N. Advances in packaging of litchi fruit to maintain the quality. Curr J Appl Sci Technol 2019;38:1-11.

15. Lal N, Sahu N. Management strategies of sun burn in fruit crops a review. Int J Curr Microbiol Appl Sci 2017;6:1126-38.
16. Singh VK, Karuna S, Tiwari NK, Rao OP. Effect of certain nutrients on fruit set, fruit retention, physical characters and yield of Ber fruit (Zizyphus mauritiana Lamk) CV. Banarasi Karaka. Int J Bio Resour Stress Manage 2016;7:648-52.

17. Lal N, Das RP, Verma, LR. Effect of plant growth regulators on flowering and fruit growth of guava (Psidium guajava L) CV. Allahabad Safeda. Asian J Hortic 2013;8:54-6.

18. Lal N, Das RP. Effect of plant growth regulators on yield and quality of guava (Psidium guajava L) CV. Allahabad Safeda. Int J Curr Microbiol Appl Sci 2017;6:857-63.

19. Ghosh B, Mitra SK. Effect of varying levels of nitrogen, phosphorus and potassium on yield and quality of litchi (Litchi chinensis Sonn) CV. Bombai. Haryana J Hortic Sci 1990;19:7-12.

20. Panse VG, Sukhatme PV. Statistical Methods for Agricultural Workers. New Delhi, India: Indian Council of Agricultural Research; 1967.

21. Waseem K, Ghaffoor A, Rehman SU. Effect of fruit orientation on the quality of litchi (Litchi chinenesis Sonn) under the agro-climatic conditions of Dera Ismail Khan-Pakistan. Int J Agric Biol 2002;4:503-5.

22. Rahman MS, Rabbi MA, Bhuiyan MZ, Ara N, Hasan MN. Consequence of fruit orientation on the quality of litchi (Litchi chinenesis Sonn) under the agro-climatic conditions of Ishardi, Bangladesh. Int J Exp Agric 2010;1:16-19.

23. Rehman S, Ahmad I, Ghafoor A, Baloch AK. Quality of sweet oranges as influenced by the fruit orientation on the tree. Pak J Sci 1982;34:65-70.

24. Nagraj K, Diwan G, Lal N. Effect of fruit load on yield and quality of litchi (Litchi chinensis Sonn). J Pharmacogn Phytochem 2019;8:1929-31.

25. Sayal NA, Sayal OU, Jatoi SA. Variation in chemical composition of litchi fruits by orientation. Pak J Biol Sci 1999;2:1080-2.

26. Rehman S, Baloch AK, Ghaffoor A. The quality of sweet oranges (Citrus sinensis) as influenced by exposure to sunlight. J Pure Appl Sci 1984;3:1-5.

27. Singh KK, Chadha KL. Factor affecting the Vitamin C content of mango. Punjab Hortic J 1961;1:171. 